It is clear that mast cells expressing different mediators, enzymes and receptors will have different functions, but what those exact roles are is not known and can only be guessed at from the current study. Nevertheless, cells which do not express FceRI are unlikely to respond to allergen, while those expressing renin are likely to influence cardiovascular function. While it may be possible to isolate individual populations based on their receptor expression, at present it is not possible to do this with respect to intracellular contents, so determining their precise function will be a challenge. Others, however, have shown variability in lung mast cell density and size and examined their response to IgEdependent activation, but these studies did not examine the anatomical location of these cells. ${ }^{24}$ Interestingly, enzymatically dispersed parenchymal human lung mast cells fractionated using countercurrent elutriation were shown to range in size from 8 to $20 \mu \mathrm{m}$, with smaller diameter mast cells consistently releasing less histamine and $\mathrm{PGD}_{2}$ than large mast cells following IgE-dependent activation. ${ }^{24}$ This differential mediator release could not be explained by cell surface $\operatorname{IgE}$ content which was similar in mast cells of all sizes. Furthermore, the concentration of anti-IgE for maximum histamine release was the same for mast cells of all sizes, suggesting similar receptor function and density. This and other studies ${ }^{26}$ do not tally with the observation of Andersson that parenchymal lung mast cells do not express FceRI, suggesting that their immunohistochemical staining procedure might lack sensitivity.

In summary, the study by Andersson and colleagues demonstrates clearly the extensive heterogeneity of human mast cells within a single organ - in this case, the lung. This is likely to extend well beyond the current findings, and there is a huge challenge ahead to unravel the precise function of these different mast cell phenotypes in both health and disease.

\section{Competing interests: None.}

Thorax 2009;64:278-280. doi:10.1136/thx.2008.106427

\section{REFERENCES}

1. Mulero I, Sepulcre MP, Meseguer J, et al. Histamine is stored in mast cells of most evolutionarily advanced fish and regulates the fish inflammatory response. Proc Natl Acad Sci USA 2007;104:19434-9.

2. Bradding $\mathbf{P}$, Holgate ST. Immunopathology and human mast cell cytokines. Crit Rev Oncol Haematol 1999;31:119-33.

3. Kalesnikoff J, Galli SJ. New developments in mast cell biology. Nat Immunol 2008;9:1215-23.

4. Kovanen PT. Mast cells and degradation of pericellular and extracellular matrices: potential contributions to erosion, rupture and intraplaque haemorrhage of atherosclerotic plaques. Biochem Soc Trans 2007;35:857-61

5. Bradding $\mathbf{P}$, Walls AF, Holgate ST. The role of the mast cell in the pathophysiology of asthma. J Allergy Clin Immunol 2006;117:1277-84.

6. Inoue $\mathbf{Y}$, King TEJ, Tinkle SS, et al. Human mast cell basic fibroblast growth factor in pulmonary fibrotic disorders. Am J Pathol 1996;149:2037-54.

7. Eklund KK. Mast cells in the pathogenesis of rheumatic diseases and as potential targets for antirheumatic therapy. Immunol Rev 2007;217:38-52.

8. Okumura S, Kashiwakura J, Tomita $\mathrm{H}$, et al. Identification of specific gene expression profiles in human mast cells mediated by Toll-like receptor 4 and FceRI. Blood 2003;102:2547-54.

9. Varadaradjalou S, Feger F, Thieblemont N, et al. Toll-like receptor 2 (TLR2) and TLR4 differentially activate human mast cells. Eur $\mathrm{J}$ Immunol 2003:33:899-906.

10. Ishizaka T, Mitsui $H$, Yanagida M, et al. Development of human mast cells from their progenitors. Curr Opin Immunol 1993;5:937-43.

11. Jensen BM, Akin C, Gilfillan AM. Pharmacological targeting of the KIT growth factor receptor: a therapeutic consideration for mast cell disorders. Br J Pharmacol 2008;154:1572-82.
12. Irani AM, Schwartz LB. Mast cell heterogeneity. Clin Exp Allergy 1989;19:143-55.

13. Welle M. Development, significance, and heterogeneity of mast cells with particular regard to the mast cell-specific proteases chymase and tryptase. J Leuk Biol 1997;61:233-45.

14. Irani AA, Craig SS, Nilsson G, et al. Characterization of human mast cells developed in vitro from fetal liver cells cocultured with murine 3T3 fibroblasts. Immunology 1992;77:136-43.

15. Irani AM, Schwartz LB. Human mast cell heterogeneity. Allergy Proc 1994;15:303-8.

16. Weidner N, Austen KF. Ultrastructural and immunohistochemical characterization of normal mast cells at multiple body sites. J Invest Dermatol 1991;96:26-30S.

17. Bradding $\mathbf{P}$, Okayama $\mathrm{Y}$, Howarth $\mathrm{PH}$, et al. Heterogeneity of human mast cells based on cytokine content. J Immunol 1995;155:297-307.

18. Hsieh FH, Sharma P, Gibbons A, et al. Human airway epithelial cell determinants of survival and functional phenotype for primary human mast cells. Proc Natl Acad Sci USA 2005; 102:14380-5.

19. Irani AA, Schechter NM, Craig SS, et al. Two types of human mast cells that have distinct neutral protease compositions. Proc Natl Acad Sci USA 1986;83:4464-8.

20. Bentley AM, Jacobson MR, Cumberworth V, et al. Immunohistology of the nasal mucosa in seasonal allergic rhinitis: increases in activated eosinophils and epithelial mast cells. J Allergy Clin Immunol 1992;89:877-83.

21. Brightling CE, Bradding P, Symon FA, et al. Mast cell infiltration of airway smooth muscle in asthma. N Engl J Med 2002;346:1699-705.

22. Jeziorska M, McCollum C, Woolley DE. Mast cell distribution, activation, and phenotype in atherosclerotic lesions of human carotid arteries. J Pathol 1997;182:115-22.

23. Andersson CK, Mori M, Bjermer L, et al. Novel sitespecific mast cell subpopulations in the human lung Thorax 2009:64:297-305

24. Schulman ES, Kagey-Sobotka A, MacGlashan DW $\mathrm{Jr}$, et al. Heterogeneity of human mast cells. $\mathrm{J}$ Immunol 1983:131:1936-41.

25. Forsythe $\mathbf{P}$, McGarvey LP, Heaney LG, et al. Adenosine induces histamine release from human bronchoalveolar lavage mast cells. Clin Sci 1999:96:349-55.

26. MacGlashan D Jr. Single-cell analysis of $\mathrm{Ca}++$ changes in human lung mast cells: graded vs. all-ornothing elevations after IgE-mediated stimulation. J Cell Biol 1989;109:123-34.

\title{
Respiratory disability: what is it, how can we measure it, what causes it and is it important?
}

\section{Philip Harber}

Respiratory disability is a significant health outcome that has important implications

Correspondence to: Professor P Harber, Division of Occupational and Environmental Medicine, David Geffen School of Medicine at UCLA, 10880 Wilshire Blvd, \#1800, Los Angeles, CA 90024, USA; pharber@ ucla.edu both for the individual patient and for society. First, "disability" represents the actual impact of the disease on the patient's life. While "impairment" (eg, loss of $200 \mathrm{ml}$ forced expiratory volume in $\left.1 \mathrm{~s}\left(\mathrm{FEV}_{1}\right)\right)$ is an abstract concept, patients are directly impacted by the ability to work or care for themselves (ie, respiratory disability) Second, functional status as manifested by respiratory disability is an integrated measure of health status and can be an effective indicator of response to treatment. Third, by working together, physicians, patients and employers may institute specific interventions to ameliorate respiratory disability. Fourth, in aggregate, disability for work due to respiratory disease has significant societal impact on overall work productivity of a society. Fifth, estimates of disease burden or years of life saved by medical interventions are commonly adjusted for the degree of disability using disability-adjusted life years. ${ }^{1}$ Finally, in many countries, regulations specify methods of evaluating the magnitude of 
respiratory disability for determining financial payments to patients, whether or not the underlying respiratory illness was or was not actually caused by work.

This issue contains an important report by Torén et $a l^{2}$ in which they showed that respiratory disability was frequent and identified several broad categories of occupational exposures (eg, dust, gas, fumes) as causes of respiratory disability (see page 339). They defined "respiratory disability" based on self-reported change in job location or job activities because of respiratory illness. Their large community-based samples and sophisticated analysis showed that certain job characteristics were significantly associated with respiratory disability.

The term "respiratory disability" may be used in many different ways, but often focuses on disability for work rather than on the impact on home or communities. Occupational respiratory disability itself has several alternative definitions. Several consider work status/location: (1) moving from one job to another; (2) changing the activities conducted in the same job; (3) leaving the work force completely. Other definitions consider (4) functional limitations at work; (5) requirement for use of assistive devices while remaining in the same job; (6) decreased earning capacity. Several of these definitions are applicable only to occupational aspects of respiratory disability, whereas others apply equally well in the home/community setting. To complicate matters further, the term "occupational respiratory disability" is sometimes restricted to the impact of pulmonary disease that was directly caused by occupational exposures such as asbestosis or allergic sensitisation occupational asthma. The impacts are multifaceted. ${ }^{3-6}$

Measurement of respiratory disability is more complex than determination of the $\mathrm{FEV}_{1}$. It may be evaluated from several distinct perspectives. For example, the report in this issue ${ }^{2}$ depends on selfreporting by the subjects that they both changed what they did at work and also that the change was consequent on their respiratory disease versus other causes. The optimal ascertainment method probably depends on the definition employed. Measures such as change in employment status or differences in wages may be objectively determinable, but may be more difficult to relate causally to respiratory disease. Administrative systems (eg, many workers compensation or disability insurance programmes) attempt to determine quantitatively the extent of respiratory disability based on measured physiological impairment. Disability is, however, also affected by both personal and social expectations.

Fundamentally, occupational respiratory disability is present when there is a mismatch between the job and the person. Traditionally, at least conceptually, this match was ascertained based on the "oxygen consumption concept"- the patient's maximal oxygen consumption was measured directly by pulmonary exercise testing or indirectly estimated from clinical pulmonary function testing. The sustainable oxygen consumption was considered to be a fixed fraction of the maximal attainable. This was then compared with the physical demand of the job expressed in terms of oxygen consumption by direct measurement or more frequently indirectly by characterisation of the arduousness of the work. Theoretically, at least, this approach to the assessment of occupational respiratory disability could be as objective as other pulmonary measures. However, while this paradigm served well for many years, it urgently needs updating. ${ }^{7}$ Job demands are multidimensional and cannot be adequately characterised by a single characteristic. Second, factors other than the patient's physiological measurements are determinants of respiratory disability.

Increasingly, jobs require only limited physical exertion but place other demands on workers. Irritant exposure is probably much more important than the physical exertion demands for persons with asthma. Whether a job includes exposure to specific sensitisers is the critical determinant of respiratory disability for persons with occupational asthma due to allergic sensitisation (eg, to latex or diisocyanates). The most important job characteristic for persons with respiratory control disorders such as sleep apnoea is the extent to which a job requires absolutely consistent alertness; over-theroad commercial truck driving may require only limited oxygen consumption/ventilation but is infeasible for many persons with respiratory sleep disorders.

Factors in addition to routine pulmonary function tests determine the extent of respiratory disability. Clinically, the presence of airway hyper-responsiveness or of respiratory sleep disorders is important. In situations of allergic sensitisation a patient may be disabled for usual work but have no discernible physiological abnormality when not exposed (eg, a surgeon with latex glove asthma). Comorbidities represent an additional important patient factor; for example, it is difficult to ascribe disability to the respiratory system per se if there is also a cardiac problem or anxiety disorder. Patients vary in their willingness to accept some discomfort (eg, mild dyspnoea) or risk of work exacerbation of asthma symptoms. ${ }^{8}$ Patients also differ in their coping mechanisms. ${ }^{9}$ Access to good healthcare services and patient compliance with medication use also determine whether a respiratory illness becomes disabling. Non-medical factors are also important intermediary determinants. Financial incentives and disincentives, such as the availability of alternative work or the extent of disability compensation payments, undoubtedly affect whether an individual remains in a job. Disability assessment should distinguish between activity limitations and restrictions on participation in activities. ${ }^{10}$

Worksite changes (commonly called "workplace accommodation") can convert a disabled worker to an able worker. Accommodations may include reassigning heavy exertion tasks, improving worksite ventilation for the individual worker or modifying work schedules. The willingness of the specific employer to invest in the accommodation and the presence of a regulatory mandate for employers to accommodate individuals with disability both have a major impact.

The plurality of factors affecting the presence and ascertainment of respiratory disability make causal inference complex. For example, the paper on respiratory disability in this issue of Thorax suggests that certain workplace exposures lead to respiratory disability. This could occur if the worker's exposures caused respiratory disease which, in turn, led to respiratory disability. However, this type of association may also occur if persons with respiratory disease of any origin are less likely to continue working in "blue collar" jobs than in others; for example, a patient with emphysema might be able to function as a professor but not as a manual labourer. Similarly, financial incentives may favour early retirement in certain occupations. Furthermore, persons with respiratory disorders may be more likely than others to "recall" the presence of dust or other exposures in their previous job.

Respiratory disability has great importance both to an individual and to society. There is a need for long-term prospective studies in order to understand the dynamics of the development of respiratory disability. Respiratory disability can be deconstructed to a series of "atomic units" such as ability to withstand mild irritant exposure or the capability to climb a ladder. ${ }^{11}$ It is important to discern whether occupational exposures have 
directly caused the functional impact limitation or if the limitation causes disability only in certain demanding occupations.

Clinicians caring for patients with respiratory disease should spend a few moments assessing whether respiratory disability is present. If so, the specific nature of the disability should be evaluated and the patient-clinician dyad should explore whether interventions such as contacting the employer or modifying the asthma medications could reduce the extent of the disability.

\section{Competing interests: None.}

Thorax 2009;64:280-282. doi:10.1136/thx.2008.108811

\section{REFERENCES}

1. Lopez AD, Mathers CD, Ezzati M, et al. Global and regional burden of disease and risk factors, 2001: systematic analysis of population health data. Lancet 2006; 367:1747-57.

2. Torén K, Zock J, Kogevinas $\mathrm{M}$, et al. An international prospective general population-based study of respiratory work disability. Thorax 2009;64:339-44.

3. Yacoub MR, Lavoie K, Lacoste G, et al. Assessment of impairment/disability due to occupational asthma through a multidimensional approach. Eur Respir J 2007;29:889-96

4. Vandenplas 0, Toren K, Blanc PD. Health and socioeconomic impact of work-related asthma. Eur Respir J 2003;22:689-97.

5. Tarlo SM, Balmes J, Balkissoon R, et al. Diagnosis and management of work-related asthma: American College Of Chest Physicians Consensus Statement. Chest 2008;134:1-41S.

6. Dimich-Ward H, Taliadouros V, Teschke K, et al. Quality of life and employment status of workers with
Western red cedar asthma. J Occup Environ Med 2007:49:1040-5.

7. Harber P. Respiratory disability. The uncoupling of oxygen consumption and disability. Clin Chest Med 1992;13:367-76.

8. Henneberger PK, Deprez RD, Asdigian N, et al. Workplace exacerbation of asthma symptoms: findings from a population-based study in Maine. Arch Environ Health 2003:58:781-8.

9. Adams RJ, Wilson D, Smith BJ, et al. Impact of coping and socioeconomic factors on quality of life in adults with asthma. Respirology 2004;9:87-95.

10. Field MJ, Jette AM. A new look. The future of disability in America. Institute of Medicine (US) Committee on Disability in America. Washington, DC: National Academies Press, 2007.

11. Harber $\mathbf{P}$, Hsu P, Chen W. An "atomic" approach to dis/ability assessment. J Occup Environ Med 1996;38:359-66.

\section{Lung alert}

\section{Vitamin D insufficiency is common and associated with complications in cystic fibrosis}

Vitamin D insufficiency (VDI) contributes to low bone mineral density (BMD) in adults with cystic fibrosis (CF). Vitamin D may improve skeletal/respiratory muscle function and upregulate antimicrobial peptides, improving immunity. This 2-year retrospective study reviewed medical records of 185 adults of mean (SD) age 29 (9) years with CF. Parameters of bone health and the relationship between vitamin D status and forced expiratory volume in $1 \mathrm{~s}\left(\mathrm{FEV}_{1}\right)$ were investigated.

The subjects (93\% white, 17\% black) had a mean body mass index (BMI) of $21.2 \mathrm{~kg} / \mathrm{m}^{2} ; 70 \%$ used multivitamins and $47.6 \%$ took vitamin D. VDI was found in $76 \%$ of patients (25hydroxyvitaminD $(25(\mathrm{OH}) \mathrm{D})<75 \mathrm{nmol} / \mathrm{l})$ and vitamin D deficiency in $23 \%(25(\mathrm{OH}) \mathrm{D}$ $<37.5 \mathrm{nmol} / \mathrm{l}$ ). VDI was associated with race (black>white), lack of vitamin D use and season. The vitamin $\mathrm{D}$ status was positively associated with lowest $\mathrm{FEV}_{1}$, independent of age, gender, BMI and race. BMD was low (lumbar spine T-scores of $<-1.0$ and $<-2.5$ in $52 \%$ and $10 \%$ subjects, respectively), non-significantly associated with vitamin D status. Over 2 years, $27 \%$ of subjects had $\geqslant 1$ vertebral fracture associated with lower $\mathrm{FEV}_{1}(\mathrm{p}<0.001)$ but not age, BMI, vitamin D or multivitamin supplementation. Multivitamins did not prevent VDI.

Patients with CF with more severe disease (greater fat malabsorption) and lower $\mathrm{FEV}_{1}$ may have decreased physical activity and sun exposure, all contributing to VDI. Low BMD is associated with vertebral fractures and kyphosis, reducing $\mathrm{FEV}_{1}$ further. This cross-sectional study could not demonstrate causality between vitamin $\mathrm{D}$ status and fractures or $\mathrm{FEV}_{1}$, but highlights the extent of VDI and skeletal morbidity in adults with CF, calling for improved screening for vitamin D status.

- Wolfenden LL, Judd SE, Shah R, et al. Vitamin D and bone health in adults with cystic fibrosis. Clin Endocrinol 2008;69:374-81.

\section{J E Ostberg}

Correspondence to: Dr J E Ostberg, Consultant in Endocrinology and Diabetes, Watford General Hospital, Watford, UK; Julia.Ostberg@whht.nhs.uk 